\title{
JULIANO GARCIA PESSANHA EM SUAS OBRAS ${ }^{50}$
}

\section{JULIANO GARCIA PESSANHA IN HIS WORKS}

\author{
Suelen Ariane Campiolo Trevizan ${ }^{51}$
}

RESUMO: A escrita de si é especialmente produtiva para se pensar o estatuto do literário, pois, a despeito das limitações inerentes à linguagem para retratar qualquer acontecimento, traz implícita uma promessa de referencialidade. Assim, quem escreve dentro do espectro autobiográfico necessariamente precisa lidar com essa aporia. O crítico, por sua vez, não pode perder de vista a diferença entre dado factual, real e ficção na leitura desse tipo de obra. Considerando essas questões teóricas, o presente ensaio analisa textos de Juliano Garcia Pessanha (1962), escritor que busca na tradição testemunhal a forma para produzir performances e heterotanatografias sobre traumas pessoais. Para compreender a especificidade desse autor, discutem-se antes os conceitos de testemunho (Agamben e Levi), autobiografia (Lejeune e de Man) e autoficção (Klinger). Por fim, retoma-se a discussão, ainda longe de terminar, sobre a relação entre vida e obra na literatura.

Palavras-chave: Juliano Garcia Pessanha; escrita de si; testemunho; autobiografia; heterotanatografia.

ABSTRACT: The self-writing is especially productive to think about the status of the literature, because, despite the inherent limitations of language to portray any event, it implies a promise of referentiality. Thus, those who write in the autobiographical spectrum necessarily have to deal with this aporia. The critic, in his turn, must not disregard the difference between factual, real and fiction while he's reading this kind of work. Considering these theoretical issues, this essay analyzes texts by Juliano Garcia Pessanha (1962), a writer who seeks in the testimonial tradition

${ }^{50}$ Referência ao livro Nietzsche em suas obras (1894), no qual Lou AndreasSalomé analisa como aspectos da vivência do filósofo atravessam a produção bibliográfica dele.

${ }^{51}$ Doutoranda em Estudos Literários pela Universidade Federal de Minas Gerais-UFMG. 
the form to produce performances and heterotanatographies about his personal trauma. To understand the specificity of this author, the concepts of testimony (Agamben and Levi), autobiography (Lejeune and de Man) and self-fiction (Klinger) are first discussed. Finally, the discussion, still far from over, that relates life to writing in literature is retaken.

Keywords: Juliano Garcia Pessanha; self-writing; testimony; autobiography; heterotanatography.

Mas eu não sofro de auto-observação. A autoobservação implicaria pensar que algo jorrasse antes para ser depois observado. Haveria uma precedência do gesto e da opacidade inomeada sobre o que é, além, clarificado. Mas não é assim que me acontece. Os nomes precedem tudo.

Juliano Garcia Pessanha, "Equação natal: presença roubada"

\section{1 "Eu sou legião"}

É tudo verdade? Aconteceu exatamente como você relata? O leitor ingênuo que sempre há dentro de nós gostaria de fazer essas perguntas aos autores que escrevem dentro do espectro biográfico - autobiografias, memórias, autoficções, diários, testemunhos etc. Se não deixamos esse impulso ir às vias de fato, é por medo de soarmos ridículo e, principalmente, por desconfiarmos de que a resposta não resolverá a inquietação que tais narrativas provocam. Certo dia, porém, cansada de escavar registros documentais sobre Juliano Garcia Pessanha e frustrada por esses serem tão escassos em plena era das redes sociais, sucumbi à tentação de lhe fazer as famigeradas perguntas. Ele respondeu ao meu email em duas linhas. Na primeira, escreveu "posso te dizer que trabalho bem rente aos acontecimentos", e abaixo, "tem teor testemunhal".

Ora, "bem rente" significa proximidade com o acontecimento, mas não coincide com o próprio, assim como o viés testemunhal também não. $O$ motivo, bem óbvio, é que a língua nunca será capaz de traduzir fielmente os acontecimentos, de modo que, por mais que se almeje à objetividade no ato de fala, todo enunciado produz equívocos. Para participar do jogo da língua, é preciso se submeter a essas regras, que 
eliminam qualquer possibilidade de se chegar à coisa em si. Somos atirados numa teia de sentidos, que percorremos ora esperançosos de atingir o fim (ao menos, algum fim), ora pressentindo que ela possa ser infinita. Talvez o melhor seja fazer como Nietzsche e abandonar de vez a intenção de buscar a coisa em si.

Meu e-mail resultou no já previsto: senti-me ainda mais ingênua, envergonhada por aquela obsessão pelo factual. Estudar a obra de um autor vivo é um privilégio quando ele está disponível ao diálogo, aberto para explicitar suas vivências, leituras e questões literárias. Mas, em se tratando de uma literatura autobiográfica, pode ocorrer de o crítico tomar o artista como o referente único ou principal da obra, um atestador da verdade no texto, conforme uma das concepções de "auctor" apresentadas por Giorgio Agamben (2008, pp. 149-150). Isso se torna ainda mais problemático quando se desconsideram as diferenças entre o dado factual, o real e a formulação ficcional. Embora todos eles vinculem-se em alguma medida aos acontecimentos e possuam uma faceta documental, não podem ser tomados como sinônimos.

De modo bastante resumido, o dado factual é o registro de ocorrências possíveis ou efetivas no mundo real ${ }^{52}$. Tendo um caráter referencial, demanda uma linguagem e uma percepção de mundo compartilhadas. Já o real, sob a perspectiva psicanalítica lacaniana, relaciona-se àquilo que não é simbolizável e que perturba qualquer visão harmoniosa de realidade. A arte contemporânea, segundo Hal Foster (2017), vale-se bastante da repetição de imagens traumáticas a fim de resgatar o real, que em geral é descartado ou banalizado na experiência cotidiana. A ficção, por fim, organiza diversos registros de fatos ocorridos ou imaginados, segundo uma coesão determinada por um autor, em parte consciente, em parte inconscientemente, sob a influência de um "espírito da época" (Zeitgeist) e de um repertório pessoal, resultando numa narrativa permeada por muitas lacunas, previstas ou não.

Para ser ainda mais explícita, o dado factual diz respeito à experiência que a linguagem pode descrever, o real, à experiência que escapa à linguagem, e a ficção, à própria linguagem. Os três são formas de se arquivar os saberes, porém os próprios acontecimentos restam intocados por essa tentativa de estabelecer a memória do acontecido. Mesmo a memória, no fim das contas, não permanece fixa, dado que o

52 BUNGE, M. A. Dicionário de filosofia. São Paulo: Perspectiva, 2002. Verbeto "fato". 
arquivo é "campo de disputa, espaço de conflito entre gêneros discursivos, choque de interpretações" (MARQUES, 2015, p. 40). Assim, o arquivo está sempre aberto para adições, exclusões, rearranjos e interpretações, à mercê de curadores e leitores.

Ora, se a documentação sobre uma vida humana é um tipo de arquivo, a própria pessoa, existência em aberto se estiver viva, ou não mais observável se morta, é aquilo que sempre escapa. Portanto, procurar a coincidência entre o "eu" que lemos nos textos biográficos, o que enuncia, o que escreveu e o que viveu é perseguir aquilo que não é acessível, tentar impor uma unidade ao que é legião. Isso ficou bastante evidente na minha convivência com Juliano Garcia Pessanha (o sujeito empírico) e sua obra. Conheci-os juntos, em um evento literário de Curitiba chamado Litercultura, ocasião em que assisti a uma palestra dele e adquiri seu livro Testemunho transiente (2015). Se autor e obra surgiram para mim como uma unidade, totalmente coerentes, conforme eu ia aumentando o contato com ambos, mais eles se distanciavam.

Alguns dos dados factuais sobre Pessanha estão reunidos na minibiografia divulgada em seus livros e site pessoal. Esse paulistano nascido em 1962 é mestre em psicologia e doutor em filosofia. Publicou Sabedoria do nunca (1999), Ignorância do sempre (2000), Certeza do agora (2002) e Instabilidade perpétua (2009), depois reunidos sob o título de Testemunho transiente. Em 2018, lançou Recusa do não-lugar e, em coautoria com Evandro Affonso Ferreira, Epigramas recheados de cicuta. Além de escrever e divulgar seus textos em eventos culturais, ele oferece cursos de escrita criativa e grupos de estudo sobre filosofia e literatura. Esses dados, facilmente localizáveis por qualquer um que pesquise sobre o autor, reforçam a percepção de que ele fala a partir de um entre-lugar disciplinar. Menos óbvio, porém, é perceber como tais informações ampliam a leitura da obra. Com base na minha experiência de leitura, acredito que acrescentam muito pouco, mal arranham as questões tratadas em seus textos ficcionais.

Os dados que fui coletando na observação de performances e palestras (a maioria assistida pelo Youtube, algumas presenciais), trocas de e-mails e conversas ao vivo parecem um pouco mais significativos para entender seu lugar de fala, embora ainda sejam limitados. Percebi que Pessanha geralmente chega bastante ansioso para se apresentar em público, mas logo se descontrai, e muito, se se convence de que está sendo acolhido pela audiência. Ao mesmo tempo em que se lamenta com frequência da saúde frágil e da falta de retorno financeiro, age com 
extrema generosidade, e não me lembro de ter visto uma fala sua em que ele não tivesse arrancado, às vezes até sem querer, risos de seus interlocutores.

Esses traços que observei em suas interações com o público também se manifestam, alguns mais presentes do que outros, no texto escrito. Lê-lo desperta tanto uma sensação de esvaziamento e angústia como uma vontade de amar o próximo incondicionalmente - indicadores de sua ressonância intensa com Nietzsche. Na primeira vez em que visitei Testemunho transiente, logo após me estremecer com a leitura de "A exclusão transfigurada", me perturbei com o ensaio sobre esse filósofo "Em louvor ao júbilo" e, ainda perplexa tentando acompanhar "Heidegger e a velha: falar e não falar sobre A origem da obra de arte", soltei uma sonora gargalhada por me deparar com uma nota de rodapé autobiográfica impossível de ser ignorada, pois ocupa mais de metade de página. Apesar da extensão, vale a pena citá-la integralmente, na esperança de que seu caráter anedótico divirta meus leitores antes de entrarmos em assuntos mais sombrios, o que não deve demorar a acontecer.

Este texto foi lido a primeira vez no ateliê de Sérgio Fingermann (Espaço Contraponto). Em novembro de 2007, cinco meses após essa primeira leitura pública, fui convidado para falar em Poços de Caldas (MG). Pensei comigo mesmo: "Acho que vou levar o textinho da Velha. Ele reverberou bem lá no Espaço Contraponto...”. Dirigime, então até Poços convicto de que tinha algo bom nas mãos, e de que a viagem seria um ótimo passeio até uma cidade querida. Chegando ao hotel, cansado da viagem, notei que havia ali uma sala de massagem, e como ainda faltava uma hora para a palestra, decidi chamar uma massagista. Dez minutos depois, sou abordado por uma senhora atarracada, vestida com um jalequinho branco. Ela me puxa pelas mãos e me leva até a salinha de massagem. Eu começo a ficar assustado, com taquicardia e, já pensando em como fugir dali, escuto: "Vamos, vamos, é só meia horinha". Antes de me tocar, ela diz uma reza estranha e depois passa em minhas costas um líquido avermelhado tirado de uma garrafinha cheia de gravetos. Cada fez mais assustado, começo a ter as costas friccionadas 
com uma força tal que penso que elas vão sangrar. Suporto a coisa toda por uns quinze minutos até que, num gesto de coragem desesperada, digo a ela que preciso dar uma conferência. Lembro-me de ir caminhando pela rua inteiramente trêmulo e angustiado, crente de que ela havia me contaminado com algo fatal. Chegando ao auditório, peço para um professor ir comigo ao banheiro, tiro a camisa e lhe mostro as costas e os ombros. Ele diz: "Não, não está sangrando. Mas está muito vermelho". Foi uma de minhas piores "conferências". Li o texto mecanicamente, sem nada acrescentar. Mal conseguia compreendê-lo. Pedia desculpas a todo momento por não estar podendo pensar. Dizia que tinha acontecido algo e que isso havia me roubado a possibilidade de falar. Ao final, uma das pessoas que assistiam à palestra me perguntou: "Mas, afinal, o que aconteceu? Foi um acidente ou um sequestro relâmpago?". Então, só então, me dei conta: "Não, foi pior! A Velha estava me esperando aqui em Poços" (PESSANHA, 2015, p. 269).

Provocara o meu riso primeiro a inserção inusitada, já que aquela nota se vinculava a uma discussão sobre a concepção heideggeriana de obra de arte e, em segundo lugar, o exagero, pois a historieta pontuada pelo suspense e pela angústia parecia excessiva para descrever uma simples massagem, ainda que ruim. Hoje, ciente da feição hipocondríaca de Pessanha - em mais de uma apresentação, ele retirou diversas caixas de comprimidos da bolsa e as posicionou à frente como uma espécie de barricada -, duvido de que houvesse nesse relato intenção humorística e imagino que ele deva ter ficado mesmo muito impressionado com a experiência relatada. Até me sinto mal por ter rido, mas nem por isso a potência cômica do texto desaparece, continuo rindo dele sempre que o releio, apesar da culpa. Isso exemplifica a incompatibilidade entre a percepção da personalidade de quem escreve e a experiência de leitura. Uma não anula a outra, afinal, a superinterpretação também é um direito do leitor.

Noutros momentos, lendo sobre o desamparo de $\mathrm{Z}$ em "Deslocamento", de Gombro em "Esse-menino-aí, de JP em "A exclusão transfigurada" e de outros desses personagens nascidos para o exterior no sentido foucaultiano, eu imaginava que seu autor deveria ser infeliz e 
deslocado. Contudo, quem eu encontrei ministrando um grupo de estudos sobre Peter Sloterdijk era um homem dotado de segurança, simplicidade e clareza próprios de quem está no seu lugar de pertença. Mais um desencontro entre o eu ficcional e o empírico.

Em seus textos ficcionais, Pessanha trata do trauma de chegar a um mundo que não ressoa consigo e, sequestrado pelas instituições tecnocratas e seus agentes, ser impelido a forjar um self inautêntico. Esse é o real que ele testemunha em sua literatura, compondo uma topografia do fora que não parece ser nunca suficiente e, por isso precisa prosseguir texto após texto, repetida e dolorosamente. Contudo, a pessoa que escreve continua vivendo e se transfigurando, de modo que muda também a memória da experiência passada, redimensionando o trauma a cada nova visita ficcional.

Pessanha parece estar hoje preocupado com questões existenciais mais no sentido prático (a subsistência material) do que filosófico e até satiriza em seu livro mais recente a postura de "pastor do Ser" adotada por ele no passado - "A minha pregação pós-metafísica estava reduzida às moças que serviam café no shopping Eldorado: eu tinha me tornado uma espécie de mestre Eckhart de shopping center" (PESSANHA, 2018, p. 78). Diante da mudança, que é inerente a toda vida humana, perguntamos novamente onde reside o "eu" da escrita biográfica: naquele que viveu, no que escreveu, no que enuncia ou no encontrado pelo leitor?

O "eu", pronome dêitico, é um lugar vazio atravessado por vários tempos e discursos, por isso devemos suspeitar da unidade da identidade. Mesmo que o autor prometa contar tudo de si com sinceridade, como Rousseau em Confissões (1782), ou mesmo que ele firme um pacto referencial com o leitor, conforme propôs Lejeune, não podemos nos esquecer daquilo que pontuamos no início deste ensaio: os enunciados são sempre equívocos. A ingenuidade pode ter sido valorizada por certa vertente do romantismo, mas não há mais espaço para ela hoje, sobretudo após Auschwitz, e os criadores de literatura contemporânea estão bem cientes disso. Até antes, com Dostoiévski, Melville, Nietzsche, Freud e outros precursores, a concepção referencial da língua (a objetividade) vinha sendo minada, até que sua afirmação hoje soa quase absurda, espécie de nostalgia do tempo em que as coisas pareciam estar em seu lugar "natural", delimitadas, evidentes e seguras. 


\section{$2 \mathrm{O}$ trauma da perda da identidade}

O aprimoramento da tecnocracia, no século XX, culminou na criação e na implantação bem-sucedida de um sistema de ordenamento social massivo para conter o que "saíra do controle". Refiro-me aos campos de concentração, instituições hediondas de sequestro, seleção, capitalização e aniquilamento de indivíduos considerados indesejados pela ideologia hegemônica. $\mathrm{O}$ ódio contra determinados grupos étnicos e sociais renascia justificado pelo discurso racional: manifestava-se despersonalizado e embasado pelos métodos científicos, com eficácia garantida na eliminação do inimigo. Apesar de o partido nazista ter saído derrotado ao fim da Segunda Guerra Mundial, o legado desse modelo higienista permanece entre nós, na forma de fantasma ou até bem vivo ${ }^{53}$, por isso é importante abordar o assunto, por mais que seja doloroso ou até impossível lembrar o que se passou.

Como relatar uma experiência assim extrema, que ultrapassa as concepções de realidade e de humano? A arte, principalmente o cinema, tomou para si essa tarefa com resultados interessantes e alguns inclusive acessíveis ao grande público, como A lista de Schindler, de Steven Spielberg, e A vida é bela, de Roberto Benigni. Há ainda museus e monumentos espalhados pelo mundo, contudo uma das formas mais contundentes de narrar um trauma, a meu ver, é justo a mais discreta, o testemunho.

Giorgio Agamben define o testemunho quanto às potencialidades da língua (langue, no sentido saussureano) em sua relação com o dentro (o previsto, a possibilidade) e o fora (o interdito, a impossibilidade). Nas suas palavras, "é uma potência que adquire realidade mediante uma impotência de dizer e uma impossibilidade que adquire existência mediante uma possibilidade de falar" (AGAMBEN, 2008, p. 147). Com a introdução à força do impossível no mundo, numa situação como a de Auschwitz, o sujeito dessa experiência resulta fraturado, dessubjetivado, daí a necessidade de um tipo próprio de relato.

53 Citei o caso dos campos de concentração alemães, mas há tantos outros. Lembremos um exemplo bem próximo: o Hospital Colônia de Barbacena, uma (assim dita) instituição de tratamento psiquiátrico onde morreram mais de 60 mil internos, sendo boa parte deles por motivo de inanição. Cf. ARBEX, Daniela. Holocausto brasileiro. São Paulo: Geração, 2017. 
Esse tipo de relato diferencia-se do arquivo, pois trata de uma experiência absurda que não é arquivável. Não se trata de simplesmente identificar o que foi dito e o que não foi, mas de se pensar a impossibilidade de dizer. O testemunho "não garante a verdade fatual do enunciado conservado no arquivo, mas a sua não arquivabilidade, a sua exterioridade com respeito ao arquivo" (AGAMBEN, 2008, p. 157). Em síntese, o testemunho não visa à mera exposição de dados verificáveis, mas revela os limites da língua diante daquilo que resiste à simbolização, o real. Assim, como bem aponta Márcio Seligmann-Silva (2003), esse não é um mero gênero literário, pois a questão que coloca, o confronto entre a experiência e a (im)possibilidade de relato, em última instância, é o cerne da discussão sobre o estatuto do literário como um todo.

Observemos como a impotência diante do trauma da despersonalização ocorre primeiro num autor de testemunho considerado clássico, Primo Levi, para depois observar de que modo Juliano Garcia Pessanha se apropria de aspectos essenciais noutro contexto. Ao longo de sua vida, Primo Levi escreveu textos testemunhais e ficcionais baseados na experiência do campo de concentração. No prefácio de É isto um homem? (1947), redigido pouco após sua libertação, ele assinala algumas características importantes do seu testemunho: foi motivado pela urgência, daí seu caráter fragmentário; não tem o fim de trazer informações inéditas nem de fazer denúncia, mas de produzir documentos para estudar a alma humana; parte da necessidade de ser ouvido, de tornar outrem participantes; e não contém nada que seja "fruto da imaginação".

Além da descrição da chegada a Auschwitz, da rotina no campo e da libertação, a reflexão sobre a linguagem é parte essencial ao texto, pois a língua do mundo livre, a única de que ele dispõe no ato da escrita, mostra-se insuficiente para contar aquele tipo de experiência. É o que se nota nestes três excertos: "nos damos conta de que nossa língua não tem palavras para expressar esta ofensa, a aniquilação de um homem” (LEVI, 1988 , p. 24), "Por que o sofrimento de cada dia se traduz, constantemente, em nossos sonhos, na cena sempre repetida da narração que os outros não escutam?" (p. 60) e, por fim, "Se os campos de extermínio tivessem durado mais tempo, teria nascido uma nova, áspera linguagem, e ela nos faz falta agora" (p. 125). Querer dizer e não poder é um eixo central do texto, daí a pertinência da reflexão de Agamben em torno da (im)potência.

Sendo a língua inadequada, o testemunho carrega uma dualidade, "uma insuficiência ou uma incapacidade" (AGAMBEN, 2008, p. 150), 
sendo seu autor uma figura não de autoridade, mas de complementaridade, aquele que fala em nome de alguém incapaz de falar e que também necessita da interlocução do outro que jamais conceberia por si só uma tal experiência em que o impossível toca o real. Nessa configuração, quem está na melhor posição para testemunhar, segundo Levi, não é o mais lúcido ou mais erudito, pois os conhecimentos deste mundo pouco esclarecem sobre o tipo de acontecimento em questão, mas o "muçulmano" ${ }^{4}$. Aquele que sofreu a despersonalização de modo mais radical, que perdeu tudo, inclusive a si mesmo, é quem melhor sintetiza a incapacidade.

Enfatizamos a importância do outro no testemunho, pois, embora seja um relato em primeira pessoa, não se trata da construção de uma personalidade, como numa autobiografia, mas de seu aniquilamento. $\mathrm{O}$ olhar alheio é o que permite o ato de testemunhar, caso contrário seria uma anulação completa dos que desapareceram em silêncio. Também se difere da autobiografia no quesito de que pouco importa a sua verificabilidade. $\mathrm{O}$ aspecto documental citado por Levi tem mais a ver com a produção de um dado material para reflexão futura sobre a condição humana do que um registro com valor de verdade, uma prova ou uma evidência. A certa altura, inclusive, ele comenta: "Hoje - neste hoje verdadeiro, enquanto estou sentado frente a uma mesa, escrevendo , hoje eu mesmo não estou certo de que esses fatos tenham realmente acontecido" (LEVI, 1988, p. 105). Parece uma contradição em relação à afirmação inicial de que nada ali era fruto da imaginação, no entanto, o registro dessa dúvida é fundamental para o testemunho, pois mostra a dificuldade de se falar do trauma, a impossibilidade de fazê-lo com objetividade e clareza, pois a língua da racionalidade faliu.

Passemos agora ao caso de Juliano Garcia Pessanha. Ao reunir seus quatro primeiros livros para publicá-los em forma de tetralogia, ele rebatizou o conjunto de "Testemunho transiente", uma escolha curiosa que eu questionei ao entrevistá-lo:

Suelen Trevizan: Com relação ao testemunho, você acha que esse é um modo mais verdadeiro de se colocar ou é só mais um subterfúgio ficcional?

Termo empregado nos campos de concentração para designar os prisioneiros mais enfraquecidos, potenciais escolhidos nas seleções para as câmaras de gás. 
Juliano Garcia Pessanha: Eu não acho que seja um subterfúgio literário. Talvez possa ser, mas essencialmente não, e até posso te dizer por quê. Porque eu li muito literatura de testemunho mesmo, o Primo Levi, Herta Müller... então, para mim, esse tipo de poder, a força do testemunho que de algum modo silencia, foi o que deu uma possibilidade para a literatura vingar por mais tempo, como se fossem se esgotando essas outras formas. Eu me coloquei em parte nessa esteira. Embora não estivesse em Auschwitz nem numa sociedade totalitária, media minha experiência como extrema, então eu me coloquei nessa linhagem testemunhal. ${ }^{55}$

Portanto, continuamos no plano das experiências radicais, embora as apresentadas por Pessanha talvez não pareçam tão extremas quanto as de Levi, sobretudo para quem se submeta às relações sociais e afetivas vigentes e as reproduz sem grandes problemas - o tipo de personalidade que Nietzsche nomeou de "camelo" em Assim falou Zaratustra (1883. 1885). O testemunho, no caso do paulistano, aparece reformulado, combinado com ensaio filosófico e caso clínico. Ademais, é caracterizado como transiente, ou seja, aquilo que não permanece, deixando ainda mais patente a negatividade desse relato, que não é arquivável segundo os dizeres da sociedade de que ele brota, excluído deste mundo já todo positivado, sem espaço para o gesto autêntico nem para o poema.

Aquele que enuncia, portanto, só tem de perpétua a instabilidade - para fazer referência ao título do quarto livro da tetralogia -, mas não se assume isso impunemente. Ao fazê-lo, corre-se o risco da incompreensão expressa em termos financeiros, pela baixa vendagem de livros, ou do estigma da loucura. Com sorte (?), a espetacularização da loucura impulsiona o mercado editorial, mas esse não é o caso de Pessanha, até porque, em geral, preferem-se os autores mortos. Já Friedrich Nietzsche foi um desses cujo desvairamento, que o cometeu nos últimos dez anos de vida, trouxe grande popularidade para sua obra.

55 TREVIZAN, S. A. C. O olhar do limiar: entrevista com Juliano Garcia Pessanha. Revista Pessoa. Disponível em: <https://www.revistapessoa.com/artigo/2612/o-olhar-do-limiar>. Acesso em: 28 mar 2019. 
Nietzsche é um dos companheiros do exterior de quem Pessanha empresta a ferida para tratar da sua própria, reforçando a já mencionada necessidade do outro para amparar o testemunho. Já na primeira linha de "O mundo estranhado: esboço de filosofia fisionômica", lê-se: "É estranho que tudo o que eu, Nietzsche, encontrei logo que cheguei ao mundo estava em estado de atrofia e diminuição" (PESSANHA, 2018, p. 15). Assim, esse "eu" primeiramente identificado como o filósofo alemão já morto, numa insólita estratégia retórica ao estilo de Brás Cubas, relatará alguns episódios vividos por ele e outros por Pessanha, este referido em terceira pessoa, o JP. Nenhum dos casos, porém, está ancorado em pesquisa documental estrita, o que permite falar é a empatia, a amizade da ferida ${ }^{56}$. Da mesma forma que esse Nietzsche é ficcional, também o JP é um personagem, apesar de isso ser menos evidente, dado que as iniciais coincidem com o nome de quem assina, mas não é aquele que escreve hoje nem com aquele que vivenciou a experiência no passado. JP é uma formulação ficcional que permite falar do trauma, mais do que resultado de uma rememoração fiel ao deveras acontecido.

Noutro texto mais adiante do mesmo livro, "Nascer para dentro, nascer para fora: a mãe, há um interessante jogo de focos narrativos. $\mathrm{O}$ narrador começa a testemunhar em primeira pessoa: "No que diz respeito à minha própria experiência de ter ficado suspenso e desenraizado a ponto de ter criado uma grande quantidade de eus" (p. 77). Algumas páginas depois, muda para a terceira pessoa: "Solto na manhã seguinte, ele - passo agora a narrar em terceira pessoa - volta para casa" (p. 82), retornando para a primeira pessoa após dois parágrafos e assim permanecendo até o desfecho. A transformação do "eu" em "ele" ocorre

${ }^{56} \mathrm{Na}$ entrevista realizada com Pessanha, já referida em nota anterior, ele se refere a esse tipo de escrita como performance: "eu chamei de performance essa operação de falar a partir de uma ferida que diz de um outro mundo, de um outro escritor com o qual eu estou em completa... como dizer? Eu identifico a dor como tão parecida que seria exatamente, voltando às perguntas anteriores, um jeito de não falar filosoficamente no sentido acadêmico, mas falar filosoficamente nesse sentido da amizade". Com relação ao tema da performance, cf. TREVIZAN, S. A. C. Da literatura: ensaio, performance e fracasso. Scripta. Belo Horizonte, v. 23, n. 47, pp. 115-126, mai 2019. 
no auge da tensão, quando o narrador retorna para a casa materna transtornado e acaba sendo internado num hospital psiquiátrico.

A variação do pronome pode indicar a perda de consciência dos próprios atos ou a dor de relembrar aqueles fatos, sendo necessário um distanciamento discursivo para tratar deles. Outra possibilidade de leitura desse abandono temporário da primeira pessoa é a percepção de como o diagnóstico psiquiátrico coisifica o ser humano, uma vez que sua vontade deixa de ser levada em consideração, impondo-se a da equipe médica. $\mathrm{O}$ doente mental, mesmo quando diz "eu”, não é considerado um sujeito, e todo o seu discurso é ignorado. Seguindo a lógica de Descartes, sem "cogito" (penso), não se pode falar em "sum" (sou).

De volta à performance sobre Nietzsche, no momento da transição entre o testemunho sobre a experiência deste e a de JP, o narrador póstumo dá o aval a seu leitor ficcional para transformá-lo em personagem: "Autorizo JP a me ler e a falar sobre mim" (PESSANHA, 2018, p. 21). Essa estratégia, tal qual a mudança de focos narrativos apontada acima, evidencia o caráter de constructo do "eu". Observemos sua complexidade: existe um homem chamado Juliano Garcia Pessanha que, ao escrever um texto, criou o narrador-personagem Nietzsche; este fala sobre JP, que fala sobre Nietzsche, que fala sobre JP... E assim segue até o infinito, sem nunca retornar diretamente ao homem Juliano Garcia Pessanha, mas sempre reelaborando a experiência deste em alguma medida. As inúmeras camadas que se revelam nesta simples enunciação não são exclusividade da sua prosa especificamente, mas estão presentes em toda escrita biográfica, tema da próxima seção.

\section{Entre o biográfico e o ficcional}

Ao apresentar sua definição de autobiografia, na década de 1970, Philippe Lejeune contribuiu para uma frutífera polêmica em torno do termo, rendendo inúmeras críticas, reformulações e criação de novos conceitos, como o de autoficção, a que voltaremos em breve. Em síntese, ele propôs que a autobiografia seria uma "narrativa retrospectiva em prosa que uma pessoa real faz de sua própria existência, quando focaliza uma história individual, em particular a história de sua personalidade" (LEJEUNE, 2008, p. 14). O pesquisador admite certa flexibilidade nesses quesitos, exceto em dois: precisa ter caráter referencial e haver identidade entre autor, narrador e personagem principal (pacto autobiográfico). Isso não significa uma narrativa completamente semelhante ao acontecimento - Lejeune não seria ingênuo nesse nível -, mas um compromisso (o assim 
chamado pacto) que o autor firma com seu leitor e que cumpre na medida do possível.

Uma das críticas mais incisivas foi a de Paul de Man, que considera problemáticas tanto a categorização da autobiografia como gênero literário, o que só evidenciaria sua inferioridade em relação a outros gêneros, quanto sua oposição ao romance no quesito da referencialidade. Para o crítico belga, a autobiografia é uma figura da leitura que ocorre em algum nível em todos os textos. "The interest of autobiography, then, is not that it reveals reliable self-knowledge - it does not - but that it demonstrates in a striking way the impossibility of closure and of totalization (that is the impossibility of coming into being) of all textual systems made up of tropological substitutions" (DE MAN, 1984, p. 71) ${ }^{57}$. Em resumo, não é possível fugir da prática autobiográfica, tampouco atingir qualquer referencial que não seja linguístico ao realizála, dado o caráter aberto do literário, em que um signo remete infinitamente a outro signos.

Além do testemunho e da performance, outro gênero característico da escrita de si praticada por Pessanha é a heterotanatografia, uma corruptela do termo "autobiografia", como se observa no paralelismo da morfologia dessas palavras (hetero/auto, tanato/bio). Um exemplo é o texto "Equação natal: presença roubada", narrado em primeira pessoa. Ali não há o emprego de diversos narradores nem sobreposição de personagens, ainda que os aliados do exterior estejam lá direta ou indiretamente mencionados, esses "outros" essenciais para dar alguma consistência ao "eu" que enuncia.

Se a convergência de autor, narrador e personagem se cumpre aqui, por que o escritor cunha um neologismo para categorizar um texto que parece constituir uma autobiografia segundo o conceito proposto por Lejeune? Pois a autobiografia, segundo justificativa do próprio Pessanha, retrataria uma vida que se realiza no mundo, e esse não é o caso da sua; daí a necessidade do novo termo: a heterotanatografia é a escrita do não nascimento (sintetizada na imagem do bebê aposentado já na chegada) enunciada a partir do ponto de vista do fora ("o olhar abismal"). Ele

57 "Então o interesse da autobiografia não é que revele autoconhecimento confiável - não faz isso -, mas que demonstre de um modo notável a impossibilidade de fechamento ou totalização (que é a impossibilidade de vir a ser) de todo sistema textual constituído de substituições tropológicas” (tradução minha). 
problematiza essa questão do gênero na composição do mesmo: "Palavras, também palavras e falas estavam lá, mas de nada adianta haver palavra se já não há real a recolher e a dizer” (PESSANHA, 2015, p. 229), apontando para a ausência de referente e para o discurso esvaziado. Outro exemplo: "Não é uma escrita subjetiva, autobiográfica. Só existe 'eu' no lado de dentro do mundo" (PESSANHA, 2015, p. 230), que indica a insuficiência da autobiografia para retratar a dessubjetivação sofrida desde o nascimento.

Assim como no testemunho e na performance, em que se recorre aos companheiros de ferida ou à transformação de si em personagemalheado, o tema principal da heterotanatografia é o trauma da exclusão, aliás, essa é a pedra angular de toda sua obra. Portanto, ainda que escreva "eu", não se chega à autoidentificação, pois o "eu" rememorado é inautêntico, resultado de inúmeros autofalseamentos. Vejamos um trecho da heterotanografia "Equação natal: presença roubada", em que se observa a presença de dois dos aliados literários que emprestam a ferida em comum, Fiodor Dostoiévski e Herman Melville (“Ah, humanidade!” é a conhecida frase final de Bartleby, o escrevente):

Um homem plantado direto na objetividade. Essa aberração é cada vez mais comum e ela foi profetizada já por Dostoiévski no final de Notas do subterrâneo. O homem, a planta-homem, deve enraizar-se antes na nascente suave do real, na delicadeza de um brotar e de um borbulhar para então e só depois colocar cabeça e corpo no mundorealidade. Antes do mundo liso da instituição há o mundo nascente do poema. [...] $\mathrm{O}$ que aconteceu para que eu ficasse engolido e destinado à migração contínua pelos penhascos da fenda? Ah, humanidade! Como eu te pressenti, e, da lonjura mais distante, como eu sonhei com os teus espaços! Eu me tornei um devoto do poema desacontecido e um simulador de humanidade. (PESSANHA, 2015, p. 227)

Notas do subterrâneo (1864), ou Memórias do subsolo noutra tradução que também circula no Brasil, é uma autobiografia fictícia (para aplicar a classificação de Philippe Gasparini) que problematiza não só a vitória do projeto racional, como aponta Pessanha, mas a estabilidade do gênero autobiográfico. "O homem do subsolo [...] sabe que o mergulho dentro de 
si não termina no horizonte da razão nem no abrigo do coração, mas se estende infinitamente no dilaceramento de sua não coincidência a si" (DUQUE-ESTRADA, 2009, p. 65). Se todo referido, inclusive o próprio "eu", é sempre provisório e se os conceitos não dão conta do processo em curso, dado que todos os discursos no mundo moderno tendem a se fixar antes mesmo da experiência ${ }^{58}$, a referencialidade na obra fica abalada, bem como o entendimento de autobiografia. Esta não pode apontar para a vida realizada e fechada, mas apenas para si própria, para a narrativa e suas limitações, como já indicava De Man no excerto citado acima.

Outro conceito geralmente associado à autobiografia é a autoficção, termo empregado pela primeira vez por Serge Doubrovsky na quarta capa de seu livro Fils (1977) em resposta à categorização de Lejeune, referindo-se ao que seria o meio termo entre autobiografia e ficção, prática já realizada por diversos escritores modernos, mas que este crítico não identificara em suas primeiras publicações sobre o tema. Passados quarenta anos, não se chegou a um consenso sobre o que definiria a autoficção, ora aproximando-se da autobiografia na intenção de revelar a verdade de si, ora da fabulação, em que um personagem semelhante ao autor vive situações imaginadas, mas sua presença constante nos debates e pesquisas tem sido profícua para se pensar a fronteira entre gêneros literários.

Como afirmou Silviano Santigo em uma reflexão sobre o hibridismo do fazer literário: "Inserir alguma coisa (o discurso autobiográfico) noutra diferente (o discurso ficcional) significa relativizar o poder e os limites de ambas, e significa também admitir outras perspectivas de trabalho para o escritor e oferecer-lhe outras facetas de percepção do objeto literário" (SANTIAGO, 2008, p. 174). Logo, a discussão sobre o limiar entre os gêneros não é mera mania taxonômica dos críticos, mas uma investigação sobre as possibilidades de se produzir (e de se ler) literatura, perguntando-se por fim o que se pode chamar de literário. Na literatura contemporânea, a resposta parece cada vez menos coincidir com uma noção tradicional de ficção (fingir, simular).

${ }^{58}$ Basta pensar na linguagem da publicidade: "amo muito tudo isso", "o lado bom da vida" etc., que oferece a narrativa antes da própria experiência, influenciando o consumidor a sentir e a narrar de certo modo. Será que alguém, após comer um Big Mac, diria espontaneamente "amo muito tudo isso" ou, após beber uma Coca Cola, "esse é o lado bom da vida”? 
Independente de qual acepção tome, a autoficção caiu no gosto da literatura contemporânea, ressoando com a inclinação do nosso tempo ao narcisismo e ao consumismo, isto é, a transformação do "eu" num espetáculo, num produto vendável. Observa-se esse traço não só nas publicações impressas, mas também em outras plataformas, como no cinema (cinebiografias), na TV (reality shows) e na Internet (popularização de aplicativos como Instagram e proliferação de celebridade no Youtube), para citar só alguns formatos mais recentes dos discursos de si, índices do interesse de arquivar os indivíduos.

Diana Klinger (2007), em sua tese de doutorado, entende o retorno do autor praticado na autoficção como um sintoma do atual egocentrismo, mas também como um olhar crítico sobre os discursos do nosso tempo, dando continuidade à crítica do sujeito fortemente praticada pelo estruturalismo e pelo pós-estruturalismo, principalmente por Roland Barthes e Michel Foucault. Coloca-se sob os holofotes o "eu", mas esse logo se percebe descentrado, necessitando de problematizar seu lugar antes de falar de qualquer outra coisa - e dificilmente chega a atingir o outro, uma vez que sua fragmentação acaba por dominar toda a narrativa, sendo esse sujeito incapaz de estabelecer sequer a si próprio. Mesmo privado de alicerce ou matéria-prima confiável, esse tipo de narrador constrói e reconstrói castelos de areia (a destruição fica por conta das intempéries, que sempre vêm), refletindo sobre tal empreitada sisífica em vez de tentar erguer uma habitação mais sólida.

A partir dessas observações, Klinger aproxima a autoficção da performance, pois ambas são um work in progress no qual o ator aparece um pouco mais do que ocorreria em uma atuação com roteiro fixo: "No texto de autoficção, entendido nesse sentido, quebra-se o caráter naturalizado da autobiografia numa forma discursiva que ao mesmo tempo exibe o sujeito e o questiona, ou seja, que expõe a subjetividade e a escritura como processos em construção" (KLINGER, 2008, p. 26). Assim, após termos passado por alguns tipos de escrita de si, o testemunho, a autobiografia (a heterotanatografia) e a autoficção, chegamos à performance, que já havia sido mencionada brevemente na seção anterior.

A prática da performance, originária do teatro, descreve bem a escrita de Juliano Garcia Pessanha, pois abala as fronteiras entre o ser e a representação, apontando para a linguagem antes como presença, gesto, poema. Essa linguagem é a que seus narradores-personagens sentem pulsar dentro de si desde o princípio, desejo de celebração da vida no 
gesto espontâneo, mas que fora impossibilitada no momento da chegada. Segundo a heterotanatografia "Esse menino-ai", apenas aos 34 anos, quando ele (Pessanha? Gombro?) se retira para seu "quarto-para-escrever" e dá vazão ao impulso censurado do poema, é que a vida começa a brotar. Como falar então em autobiografia, se não havia vida antes do discurso? Mas como não falar nela se a vida se origina da mesma fonte que a escrita sobre a vida?

\section{Considerações finais}

Este é o momento em que a leitora poderia se redimir por sua ingenuidade inicial, ostentar algumas afirmações bem fundamentadas para que perdoassem e esquecessem seu deslize anterior, mas, em vez disso, ela-eu chegamos ao fim deste percurso ainda indecisas, incapazes, ou melhor, sem intenção alguma de determinar que nosso objeto de estudo pertença a este ou àquele gênero. As fronteiras, apenas isso eu gostaria de deixar claro se possível, são maleáveis, o que não significa que valha tudo, que não haja o que discutir. Da mesma forma que, seguindo o exemplo de Nietzsche, rejeitamos as definições demasiadas fixas e atemporais, resistamos ao relativismo absoluto no outro extremo. Se estamos tratando de algo não arquivável - a vida, os devires -, é legítimo ao menos o desejo de descrever o movimento (a escrita). Faço isso ciente de que é o rastro de algo inapreensível em sua totalidade, mas que a experiência lacunar também é tudo que conhecemos sobre a vida, portanto não está tão distante assim dela. Está "bem rente aos acontecimentos".

Tanto o testemunho quanto a performance, a autobiografia (a heterotanatografia) e a autoficção revelam o aspecto fragmentário da reconstrução da experiência, portanto aderem ao gesto iterativo de Pessanha ao traçar uma topologia desse fora que lhe impingiram. Não há uma narrativa única que dê conta do trauma, por isso é preciso continuar escrevendo, escrevendo, para que na repetição se vislumbre o que não pode ser simbolizável, o real. Cada vez que esse escritor se coloca diante do público, arma sua barricada de comprimidos e lê seus textos, eu percebo que ele sofre em diversos níveis: sofre por lembrar, por expor o corpo ferido, por duvidar de que tenha encontrado a melhor forma de dizer, por temer que não o compreendam... E quem pode dizer com certeza que compreendeu o que ele viveu? Apenas posso dizer que ele encontrou um modo muito potente de fazer ecoar sua dor, tornando-se 
também ele próprio um aliado e oferecendo uma amizade da ferida ao leitor.

\section{REFERÊNCIAS}

AGAMBEN, G. O que resta de Auschwitz: o arquivo e a testemunha. São Paulo: Boitempo, 2008.

BUNGE, M. A. Dicionário de filosofia. São Paulo: Perspectiva, 2002.

DE MAN, P. Autobiography as de-facement. In: . The rhetoric of Romanticism. New York: Columbia University Press, 1984.

DUQUE-ESTRADA, E. M. Devires autobiográficos: a atualidade da escrita de si. Rio de Janeiro: NAU; Editora PUC-Rio, 2009.

FOSTER, H. O retorno do real: a vanguarda no final do século XX. São Paulo: Ubu, 2017.

KLINGER, D. I. Escritas de si, escritas do outro: o retorno do autor e a virada etnográfica. Rio de Janeiro: 7Letras, 2007.

KLINGER, D. I. Escrita de si como performance. Revista Brasileira de Literatura Comparada. Niterói, n. 12, pp. 11-30, 2008.

LEJEUNE, P. O pacto biográfico: de Rousseau à Internet. Belo Horizonte: Editora UFMG, 2008.

LEVI, P. É isto um homem? Rio de Janeiro: Rocco, 1988.

MARQUES, R. Arquivos literários: teorias, histórias, desafios. Belo Horizonte: Editora UFMG, 2015.

NORONHA, J. M. G. (org.). Ensaios sobre a autoficção. Belo Horizonte: Editora UFMG, 2014.

PESSANHA, J. G. Recusa do não-lugar. São Paulo: Ubu, 2018.

PESSANHA, J. G. Testemunho transiente. São Paulo: Cosac Naify, 2015.

SANTIAGO, S. Meditação sobre o ofício de criar. Aletria. Belo Horizonte, v. 18, jul-dez, pp. 173-179, 2008.

SELIGMANN-SILVA, M. O testemunho: entre a ficção e o "real". In: (org.). História, memória, literatura: o testemunho na era das catástrofes. Campinas: Ed. Unicamp, 2003.

TREVIZAN, S. A. C. Da literatura: ensaio, performance e fracasso. Scripta. Belo Horizonte, v. 23, n. 47, pp. 115-126, mai 2019.

TREVIZAN, S. A. C. O olhar do limiar: entrevista com Juliano Garcia Pessanha. Revista Pessoa. Disponível em: 


\section{8 | Suelen Ariane Campiolo Trevizan}

<https://www.revistapessoa.com/artigo/2612/o-olhar-do-limiar>. Acesso em: 28 mar 2019.

Recebido em: 21/08/2019

Aceito em: 14/09/2019 